\title{
Social networks and fishers' behavior: exploring the links between information flow and fishing success in the Northumberland lobster fishery
}

\author{
$\underline{\text { Rachel A. Turner }}^{1}, \underline{\text { Nicholas V. C. Polunin }}^{2}$ and Selina M. Stead ${ }^{2}$
}

\begin{abstract}
Fisheries worldwide are facing overexploitation, yet the social dimensions of fishers' behavior remain under-studied, and there is demand for an improved understanding of social processes that influence fisheries' dynamics. Fishers draw on social relationships to acquire information relating to fishing opportunities, contributing to knowledge that underpins decision making and behavior. In this study we use quantitative social network analysis (SNA) to compare the structure of information-sharing networks and explore links between information flow and fishing success at four ports in the Northumberland (UK) potting fishery. In our results we describe the different information-sharing networks existing at each port, and show the following: a high proportion of fishers reported sharing information, though fewer than a third of reported ties were reciprocated; subgroups existed in which greater information sharing occurred; and networks displayed varying levels of cohesiveness. Fishers commonly shared information with others whom they perceived to be successful, and reciprocal relationships were more common among fishers of similar success. Furthermore, fishers more central in networks had more sources of incoming information through social relationships, shared information with fewer peers, and were more successful than those who were less central. We conclude that engaging in information-sharing networks can provide benefits for Northumberland fishers, although advantages gained through social networks may not be equally distributed. Although informationsharing networks may contribute to fishing success, i.e., high lobster landings, these outcomes may not be compatible with long-term fisheries management objectives. Nevertheless, understanding the social dynamics of information sharing can help inform management strategies by identifying central fishers in information-sharing networks, who have access to a range of information on others' fishing behavior. Such fishers may be able to assist managers in collecting information on the distribution of fishing opportunities, the state of the fishery, and the ways in which fishers use their knowledge to adapt to change and management interventions.
\end{abstract}

Key Words: fisheries management; fishers' behavior; fishing success; information sharing; lobster fisheries; social network analysis

\section{INTRODUCTION}

It is widely recognized that an inadequate understanding of fishers' behavior has contributed to failures of modern fisheries management worldwide (Hilborn 1985, 2007). Fishers' behavior is influenced by many factors, including technological, ecological, and economic variables, e.g., vessel power, target species distribution, and markets. Underpinning fishers' decision making in the context of these variables is knowledge of the marine environment (Johannes et al. 2000, Salas and Gaertner 2004, Marchal et al. 2006, Grant and Berkes 2007). Decisions about where to fish are informed by fishers' knowledge, which helps mitigate the uncertainty created by spatial and temporal variation in target species (Cashdan 1983, Mangel and Clark 1983, Wilson et al. 2007).

Knowledge can be considered to be an individual or a social asset. At an individual level, fishers accumulate a rich qualitative knowledge through experience of fishing grounds over time (Johannes et al. 2000). Differing experience means knowledge may vary among individuals, influencing awareness of fishing opportunities, behavior, and fishing success (Branch et al. 2006). The view of knowledge as an individual asset is supported by arguments proposing secrecy as a beneficial strategy in competitive fisheries, where fishers conceal information about their catches and fishing locations (Palsson 1982, Allen and McGlade 1986, Palmer 1991). However, mounting evidence suggests knowledge should be considered a social asset because, despite competition, fishers engage in social relationships to share information (Acheson 1981, Gatewood 1984, van Ginkel 2001, Salas and Gaertner 2004, Mueller et al. 2008). Fishers draw on social relationships to acquire information that contributes to decisions about when and where to fish (Gezelius 2007). Such relationships can increase fishing efficiency by reducing time spent searching for productive grounds (Rudd 2003). Heterogeneity in fishers' decisions about whether to share information, and with whom, mean that different fishers may have access to different information.

Although qualitative studies have emphasized the importance of information flow, only recently have quantitative studies of fishers' behavior begun to incorporate social variables such as information sharing (Allen and McGlade 1986, Little et al. 2004, Little and McDonald 2007, Wilson et al. 2007, Wilson and Yan 2009), and the social dimensions of fishers' behavior remain under-studied (van Putten et al. 2012). Given the importance of social relationships in acquiring information and building knowledge, a social network approach is useful to explore the dynamics of information sharing and how it relates to fishing success. Social network analysis (SNA) provides a tool to examine these theories empirically by quantifying properties of social networks and the positions of individuals within them. SNA can be defined as the study of social-relational systems comprising data on a set of actors, their attributes, and the relationships among them (Wasserman and Faust 1994). Social science research has long employed SNA (van Duijn and Vermunt 2006, Borgatti et al. 2009), and its potential to offer insight into network properties with implications for natural resource management is increasingly recognized (Bodin et al. 2006, Bodin and Prell 2011), particularly in relation to fisheries governance (Maiolo and Johnson 1989, Johnson and Orbach 1990, Crona and Bodin 2006, 
Bodin and Crona 2008, Ramirez-Sanchez and Pinkerton 2009, Hartley 2010, Hartley and Glass 2010, Marín and Berkes 2010, Bodin and Prell 2011). However, the application of empirical research and quantitative analysis to networks to date is limited (Bodin and Crona 2009).

In this study we contribute to the growing literature on SNA and fisheries by exploring the relationship between informationsharing networks and fishing success in the Northumberland lobster fishery in the UK. We hypothesize that engaging in information-sharing networks contributes to greater fishing success because information relating to the fishing grounds and catches of other vessels contributes to improved knowledge of fishing opportunities. The Northumberland fishery provides an opportunity to explore the value of information sharing in fishing success, because the relatively low mobility of lobsters (Smith et al. 2001) is expected to lead to knowledge of resource distribution that is valuable to resource users for longer than in cases where target species are more mobile (Acheson 1981, Palmer 1991). The analysis of whole networks, including data on all individuals in a network, can involve time-consuming data collection; therefore the small population of resource users in Northumberland fishing communities provides a feasible context for investigating these links, using a whole-network approach. Our objectives are described below.

Objective 1: To describe and compare the network structure at four ports in Northumberland, chosen for their diverse characteristics. Structural properties of networks represent underlying social processes among resource users, e.g., information sharing, the outcomes of which, e.g., fishing success, can have implications for individuals within the network (Little and McDonald 2007, Bodin and Crona 2009). We compare the structure of the four networks at the four ports using four metrics relevant to information sharing. First, we consider the number of information-sharing ties reported, because it is expected that highly connected networks should result in greater information flow (Bodin and Crona 2009). Second, we measure reciprocity in reported ties. Reciprocal ties are considered stronger than asymmetric ties because reciprocity is believed to increase trust and long-term obligations, which are important for informationsharing relationships (Pretty 2003). Third, we consider network fragmentation, because the extent to which subgroups occur and the interaction between them can have implications for the flow of information, and thus for the development of fishers' knowledge (Crona and Bodin 2006, Bodin and Crona 2009). Finally, we compare network centralization, which describes the extent to which receipt of information, and therefore potential competitive advantage, is dominated by a few individuals or spread evenly among fishers.

Objective 2: To understand patterns of relations among fishers. Recent studies of farmers and fishers have found direction of information flow to be important in social networks (Mueller et al. 2008, Henrich and Broesch 2011, Van den Broeck and Dercon 2011). Fishers' choices of whom to share information with are expected to reflect their perceptions; those who are seeking to learn preferentially connect to others who they anticipate possess information that can be acquired (Henrich and Broesch 2011). Our first hypothesis is that fishers are more likely to report information-sharing ties with others whom they perceive to be similarly successful or more successful than they are themselves.
Qualitative research suggests information-sharing relationships occur among fishers who anticipate a reciprocal exchange of information to be beneficial (Acheson 1988). Our second hypothesis is therefore that reciprocal relationships are more likely among fishers of similar success rates.

Objective 3: To explore the relationship between fishing success and fishers' positions in a network. An individual's position in a network can confer opportunities or constraints (Bodin et al. 2006, Ernstson et al. 2008, Borgatti et al. 2009). Social capital theory suggests that individuals with more social connections may have access to broader knowledge and may perform better than those with fewer ties (Crona and Bodin 2006, Carlsson and Sandström 2008). Because information about where and when others are successful can contribute to individuals' knowledge of fishing opportunities, our third hypothesis is that fishers who receive information through a greater number of social ties will be more successful.

\section{METHODS}

\section{Study area}

\section{Geography and resources}

The study area stretches from the River Tyne to the northern boundary of Northumberland, where inshore fishing (to $6 \mathrm{nmi}$ [nautical miles] from the coast) is managed by the Northumberland Inshore Fisheries and Conservation Authority (NIFCA, Fig. 1). The potting fishery uses baited pots (traps/ creels) to target predominantly European lobster (Homarus gammarus), brown crab (Cancer pagurus), and velvet swimming crab (Necora puber). Lobster is distributed along the coast in rocky substrata, from the shore to approximately $60 \mathrm{~m}$ depth (NIFCA 2013), and potting is geographically restricted by habitat availability and potential conflict with trawling vessels offshore. The extent of suitable habitat varies throughout the district, being restricted to within $6 \mathrm{nmi}$ in the south, and extending beyond 12 nmi further north.

Fig. 1. Map of the Northumberland Inshore Fisheries and Conservation Authority (NIFCA) district and local shellfish ports.

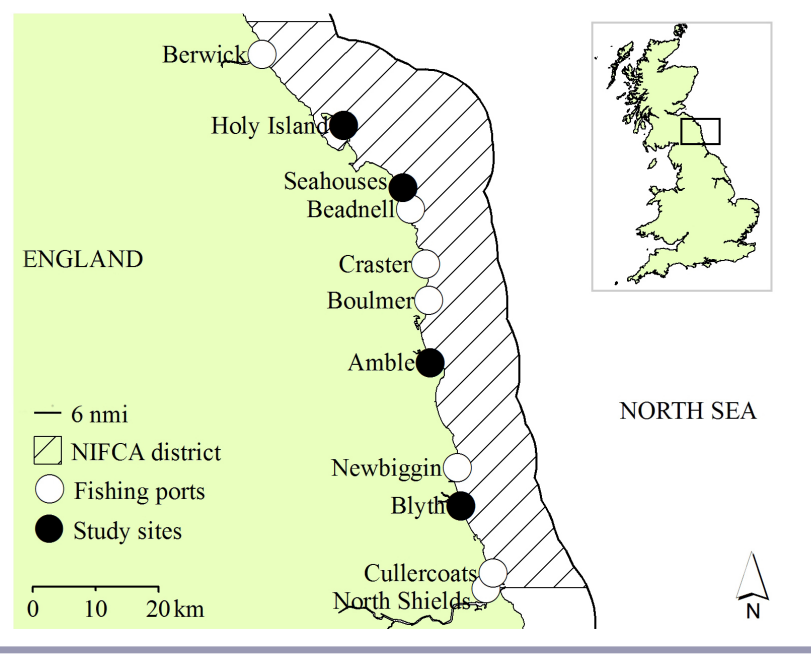


Table 1. Summary of data collected and characteristics of fishers interviewed at each port. Estimated relational data lost was calculated as $100-k$, where $k$ is the sample size as a percentage of the population (Burt 1983). Data on fishers, gear, and vessels reflect characteristics of the interview sample.

\begin{tabular}{|c|c|c|c|c|}
\hline Port and fisher characteristics & Blyth & Amble & Seahouses & Holy Island \\
\hline \multicolumn{5}{|l|}{ Port characteristics } \\
\hline Population (2001 census) & 35,691 & 6044 & 1803 & 162 \\
\hline Main fishing activities & $\begin{array}{l}\text { Potting, } \\
\text { trawling }\end{array}$ & $\begin{array}{l}\text { Potting, } \\
\text { trawling }\end{array}$ & Potting & Potting \\
\hline Active fishers & 11 & 17 & 9 & 6 \\
\hline \multicolumn{5}{|l|}{ Network data collected } \\
\hline Fishers providing network data $(\%)$ & $10(91)$ & $16(94)$ & $9(100)$ & $6(100)$ \\
\hline Estimated relational data lost (\%) & 9 & 6 & 0 & 0 \\
\hline \multicolumn{5}{|l|}{ Fisher characteristics } \\
\hline Mean fisher age (SE) & $47(3)$ & $52(3)$ & $42(4)$ & $56(5)$ \\
\hline Mean years fishing experience (SE) & $23(3)$ & $29(4)$ & $25(3)$ & $40(5)$ \\
\hline Past generations fishing ( $\%$ respondents) & $5(50)$ & $13(87)$ & $9(100)$ & $6(100)$ \\
\hline Current family fishing ( $\%$ respondents) & $4(40)$ & $10(63)$ & $5(56)$ & $3(50)$ \\
\hline Other source of income ( $\%$ respondents) & $2(20)$ & $3(20)$ & $2(22)$ & $1(17)$ \\
\hline \multicolumn{5}{|l|}{ Fishing gear and vessels } \\
\hline Mean vessel length $(\mathrm{m})(\mathrm{SE})$ & $9.0(0.56)$ & $7.8(0.47)$ & $9.9(0.35)$ & $8.5(0.51)$ \\
\hline Mean engine size $(\mathrm{kW})(\mathrm{SE})$ & $106(28)$ & $56(11)$ & $187(43)$ & $119(39)$ \\
\hline Mean lobster pots (SE) & $410(60)$ & $388(55)$ & $637(74)$ & $575(101)$ \\
\hline Mean months fishing per year (SE) & $8.2(0.5)$ & $10.6(1.2)$ & $11.3(0.7)$ & $12.0(<0.1)$ \\
\hline Fishers using other fishing gear $(\%)$ & $4(40)$ & $9(56)$ & $3(33)$ & $0(0)$ \\
\hline
\end{tabular}

\section{Fishing practices and markets}

Lobster is a high-value species with market demand in mainland Europe; in 2008, 132 potting vessels in the district landed 204 tonnes of lobster (UK Marine Management Organisation, personal communication 2010). Lobster forms the most economically valuable part of the catch, thus is preferentially targeted by fishers, particularly during peak lobster season, JulyOctober. Potting vessels in the district are between 4 and $12 \mathrm{~m}$ in length, and can work in excess of 2000 pots (NIFCA, personal communication 2008). Outside peak lobster season, pots are often deployed on different ground types to target other species (C. J. Garside, P. M. Edward, and C. L. J. Frid, unpublished manuscript). A number of vessels operate pots seasonally or part-time, together with other fishing gear or occupations.

\section{Fishing communities and site selection}

Social characteristics vary among the 11 main ports within the NIFCA district. Larger, more urban communities are generally located in the south of the district and are home to trawl fleets in addition to potting vessels. These fishing communities have experienced some social stratification as seasonal and part-time newcomers have entered the fishery, often with little or no fishing background (local fishers, personal communication 2009). Many smaller, more rural ports further north in the district are considered to be more traditional and close-knit communities, where fishing is commonly undertaken by generations of the same families and forms a component of local tourism (NIFCA, personal communication 2008). Data were collected at four ports selected to obtain a geographic spread and capture a range of port and fleet characteristics: Blyth, Amble, Seahouses, and Holy Island (Fig. 1, Table 1).

\section{Management challenges}

Despite stocks of some shellfisheries being exploited beyond recommended levels, e.g., lobster (CEFAS 2011) and crab (ICES 2012), limited management is in place for UK lobster fisheries, and measures often are enforced under local bylaws. Although lobster fishing has traditionally been a seasonal activity, increased vessel and gear efficiency have led to a tendency for year-round potting (Phillipson and Symes 2001). Anecdotal evidence of increased fishing gear and investment in specialized potting vessels have raised concerns about long-term sustainability of the lobster fishery, leading to consideration of a rights-based management system (Defra 2011). However, inshore fisheries are not well studied at local levels, and data needed to inform management measures are lacking, including information on the allocation of inshore fishing activity (Defra 2010). The potential for fishers' knowledge to help build a more accurate picture of fishing behavior and the biological resources, considered key to achieving sustainable fisheries, is recognized by local managers (Defra 2010; NIFCA, personal communication 2008).

\section{Data collection}

The target population was defined as skippers of active potting vessels in the four ports, because preliminary interviews indicated skippers made decisions about fishing locations. Fishing behavior in Northumberland displays evidence of territoriality among groups defined by their home port (Turner et al. 2013), thus each port was considered to represent one social network. Attempts were made to conduct semistructured interviews with all skippers in each network to obtain data on whole networks. Forty-one fishers were interviewed, representing over $90 \%$ of the target population at each port (Table 1). 
Information-sharing relationships were elicited by asking fishers with which other fishing vessels or skippers they shared information about fishing location or catch. Questions were initially asked using a recall method, and respondents were subsequently prompted using a list of active vessels from the relevant port. Most respondents listed other skippers, though some recalled ties by vessel name or occasionally by crew. We assumed vessel crew possess similar information to skippers regarding recent fishing trips, and that information is shared between skipper and crew on the same vessel, therefore all reported links between vessels were recorded as ties. These information flows are interpreted as ties between fishers for the following reasons: (1) the majority of interactions reported were directly between skippers, (2) $40 \%$ of skippers work with no crew thus any ties reported with these vessels equate to ties with skippers, and (3) we assume that any information shared with crew contributes to the knowledge base of skippers, who bear ultimate responsibility for decisions about where to fish.

Network links were based on perceived ongoing communication patterns, and fishers were not asked to report frequencies of interaction. Previous studies have found recollections of specific interactions may not match observations of the same interactions, but better reflect patterns of behavior over time (Freeman et al. 1987, Krackhardt 1987). Furthermore, perceptions of relations may be more important in exploring behavior than observed interactions (Borgatti et al. 2009), particularly in informationsharing relationships, where degree of trust and quality of information shared are not easily observable.

Respondents were asked to name potting fishers they considered to be successful, to obtain a metric of fishing success derived from peer perceptions. The perceived success of individuals was calculated as the percentage of their peers who named them as successful. This metric was used as fishers' perceptions of the influence of others with whom they form relationships. Since fishers preferentially target lobster, the validity of perceived success as a metric was assessed through Spearman's rank correlation, using total lobster landings $(t)$ of each interviewee (where available, $n=35$ ) in 2007; data were from NIFCA and the UK Marine Management Organisation. Peer perceptions of fishing success were positively correlated with fishers' lobster landings $\left(r_{s}=0.659, p<0.001\right)$, indicating that fishers' perceptions of success reflected high total catches.

\section{Data analysis}

\section{Network structure}

A relational matrix based on reported information-sharing ties was analyzed using Ucinet (Borgatti et al. 2002). Recalled relationships included a small number (four or fewer per port) of ties outside the defined network boundaries, consistent with previous research showing social-spatial groupings to be closely related to fishers' home port and gear type (St. Martin and HallArber 2008). Only ties between fishers within the network boundaries were included in comparison of networks.

Ties were dichotomous, indicating presence or absence of information sharing, and were directed, indicating the direction of reported information flow. One-way information flows were possible; for example, fisher A may report sharing information with fisher $B$ without $B$ sharing information with $A$. Ties between nodes (fishers) were plotted in NetDraw (Borgatti 2002), using a multidimensional scaling technique in which node position depends on number of ties. Nodes with similar patterns of ties are positioned close to each other (Scott 2000).

The number of ties in each network is reported, together with network density, which describes the ties reported as a proportion of the possible ties within the network. Density is dependent on network size, with larger networks tending to be less dense, because the time and effort involved in social relationships limits the maximum number of ties each actor can maintain (Scott 2000). Given the small size of networks studied here, we expect density to provide a comparable measure; however, in addition we considered the mean number of ties per node in each network. The proportion of reciprocal ties was also calculated in each port. The number of components (subgroups that are not connected to each other), and isolates (fishers who were not connected to any others) were reported, to illustrate network cohesion. The components reported are both weak components, which take account of the presence or absence of ties, and not of their directionality, and strong components, which consider the directionality of ties between subgroups (Scott 2000).

Network centralization was calculated using individual indegree centrality scores (representing incoming information at each node) to assess the distribution of information received by fishers in the network (Freeman 1979). Network centralization measures are based on a scale reflecting two opposing theoretical positions: a network in which all actors are equally connected (0.0), and one that is entirely centralized around one central node (1.0). In a highly centralized network, in-centrality scores are unevenly distributed, indicating that a small number of individuals receive information from many others, whereas others receive little information. Centralization scores were interpreted in conjunction with network density to assess overall network cohesion; in two networks with similar density, the one with lower centralization can be considered more cohesive, with more equal distribution of information among ties in the network (Prell 2011).

\section{Patterns of information-sharing relationships}

Patterns of relationships were assessed using relational contingency table analysis to test two hypotheses: (1) that fishers were more likely to report sharing information with others who were equally successful or more successful than themselves, and (2) that reciprocal information-sharing relationships were more likely to occur among fishers perceived to be successful than between successful and unsuccessful fishers. Relational contingency tables report the ratios of observed ties to those expected by chance in a network with the same size and number of ties. Significance values were calculated by comparing the observed value to an underlying distribution estimated using a randomization procedure (Borgatti et al. 2002).

Network position and fishing success

The relationship between fishing success and position in information-sharing networks was assessed using degree centrality (Freeman 1979). Centrality measures the extent to which actors hold a central position in a network; high degree centrality indicates that an actor has direct ties with many others in the network (Wasserman and Faust 1994, Scott 2000). When 
Table 2. Summary of information-sharing networks reported in four ports. Components include more than one fisher; isolates are fishers that are not connected to any others.

\begin{tabular}{|c|c|c|c|c|c|}
\hline $\begin{array}{l}\text { Structural } \\
\text { properties }\end{array}$ & Measure & Blyth & Amble & Seahouses & Holy Island \\
\hline \multirow[t]{3}{*}{ Connectivity } & Total number of ties & 22 & 33 & 12 & 17 \\
\hline & Mean ties per fisher & 2.0 & 1.9 & 1.3 & 2.8 \\
\hline & Network density & 0.22 & 0.13 & 0.17 & 0.57 \\
\hline Reciprocity & Proportion of ties reciprocated & 0.16 & 0.22 & 0.2 & 0.31 \\
\hline \multirow[t]{2}{*}{ Components } & Weak components (isolates) & $1(0)$ & $2(1)$ & $1(2)$ & $1(0)$ \\
\hline & Strong components (isolates) & $2(4)$ & $3(5)$ & $2(2)$ & $1(0)$ \\
\hline Centralization & $\begin{array}{l}\text { Centralization of in-centrality scores } \\
(\%)\end{array}$ & 0.33 & 0.20 & 0.52 & 0.28 \\
\hline
\end{tabular}

applied to directed data, degree centrality comprises two parts: for each fisher, out-degree centrality reflects the number of ties reported by the fisher, i.e., representing information shared with others, and in-degree centrality reflects ties reported by others, $i$. e., incoming information to the fisher. Centrality measures were normalized as a proportion of the maximum possible measure in each network, to enable comparison of the four networks of different sizes. Linear multiple regression, computed using ordinary least squares, was used to assess relationships between centrality measures and perceived success. Success was treated as a dependent variable, and in-degree and out-degree centrality were treated as predictor variables.

\section{RESULTS}

\section{Network structure}

We present sociograms to illustrate the structure of informationsharing networks at each port and to visualize the level of connectivity, reciprocity, fragmentation, and centralization in each network (Fig. 2). Networks contained between 12 and 33 ties, and network density (the proportion of ties realized) was lowest in Amble (0.13) and highest in Holy Island (0.57, Table 2). Although Holy Island had the fewest fishers, the mean number of incoming or outgoing ties per fisher was higher than in all other ports (2.8 per fisher, Table 2$)$. The proportion of ties reciprocated was also highest in Holy Island (0.31, Table 2). Of fishers interviewed, $81 \%$ reported sharing information with others, and 8 fishers reported not sharing any information. We identified a total of three isolated nodes with no information-sharing relationships (Fig. 2).

Two weak components were evident in Amble (Fig. 2b), indicating subgroups between which no information sharing occurred. Every other network comprised a single weak component, in which each fisher could reach every other by a direct or indirect path (Fig. 2). When the direction of ties was taken into account, two to three strong components plus a number of isolated nodes were identified in each network except Holy Island, indicating closer interactions within network subgroups (Table 2). When only reciprocal ties were considered, the majority of fishers in all ports except Holy Island were isolated, with a maximum of four nodes in a single connected component (Fig. 2). All other reciprocal relationships comprised single dyads or triads (Fig. 2).
Fig. 2. Social network diagrams showing information-sharing ties in (a) Blyth, (b) Amble, (c) Seahouses, and (d) Holy Island. Circles (nodes) represent fishers. Red circles represent fishers interviewed; unshaded circles indicate fishers not interviewed. Adjacent labels represent fisher identification numbers, and circle size represents the number of times a fisher was named as successful by peers. Arrows and lines indicate direction of communication flow. Black lines indicate reciprocal flow; gray lines indicate unreciprocated flow. Graph layout is based on multidimensional scaling (MDS).

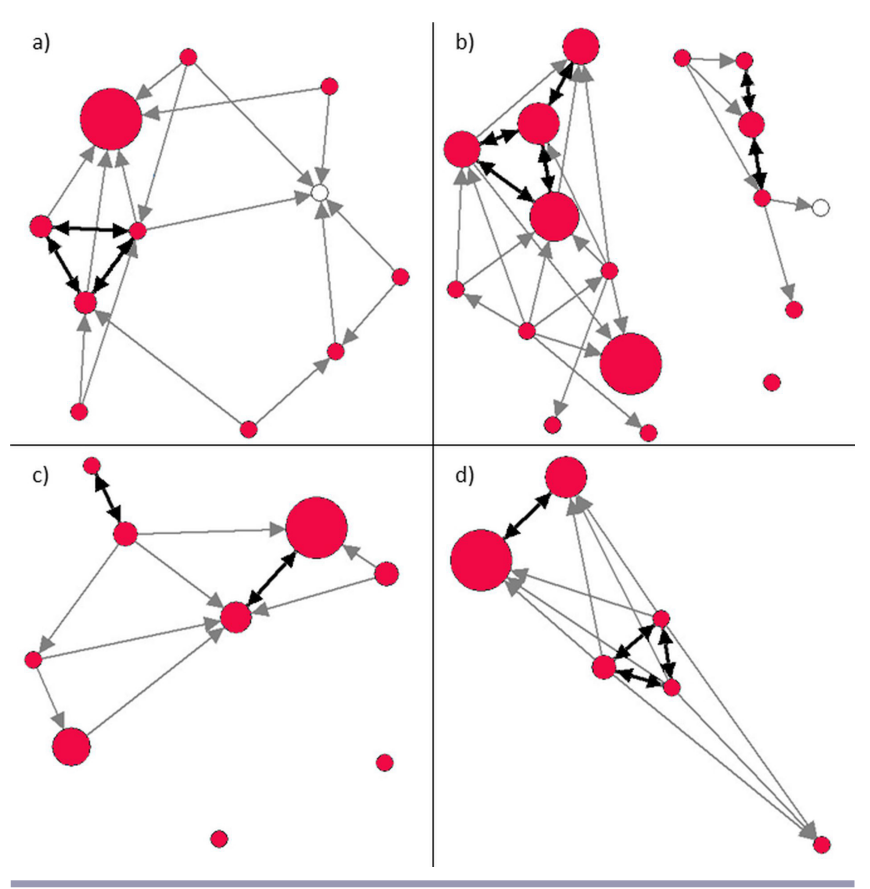

Network centralization was highest in Seahouses (0.52) and lowest in Amble (0.20, Table 2). Centralization measures indicate that access to information varies, and positional advantages gained from information sharing are unequally distributed within each port. In combination with density measurements, centralization scores indicate that Holy Island was the most cohesive network, with high density and low centralization. In 
contrast, Seahouses displayed low density and high centralization, suggesting that it had the lowest levels of network cohesion among the four ports (Table 2).

\section{Patterns of information-sharing relationships}

Relational contingency table analysis indicated that informationsharing ties directed from unsuccessful to successful fishers and between successful fishers were greater than expected by chance at all ports, with statistically significant differences demonstrated in Blyth and Amble (Table 3). In Seahouses all ties were less frequent than expected by chance except those among successful fishers. Information-sharing ties from successful to unsuccessful fishers were lower than expected by chance in all ports. This was supported by qualitative data; one fisher stated, "There's no malice in not sharing with some that aren't very successful ... they tend to just plod along and follow others, and they can't teach you anything."

Table 3. Patterns of information-sharing between "successful" (S) and "unsuccessful" (U) fishers. For example, S-U indicates successful fishers sharing information with unsuccessful fishers. Fishers denoted $\mathrm{S}$ are perceived as successful by at least one of their peers. Numbers in cells represent the ratio of observed to expected information-sharing ties. Values greater than 1 indicate ties observed more frequently than expected. Significance values are based on 1000 permutations.

\begin{tabular}{|c|c|c|c|c|c|c|}
\hline Port & $\mathrm{S}-\mathrm{U}$ & $\mathrm{U}-\mathrm{U}$ & U-S & S-S & $x^{2}$ & Significance \\
\hline \multicolumn{7}{|c|}{ Directed relationships } \\
\hline Blyth & 0.42 & 0.80 & 1.46 & 3.33 & 9.61 & 0.047 \\
\hline Amble & 0.25 & 0.60 & 1.50 & 3.02 & 23.52 & 0.004 \\
\hline Seahouses & 0.60 & 0.00 & 0.90 & 2.10 & 6.60 & 0.150 \\
\hline Holy Island & 0.59 & 1.18 & 1.18 & 1.18 & 1.24 & 1.000 \\
\hline \multicolumn{7}{|c|}{ Reciprocal relationships } \\
\hline Blyth & 1.53 & 0.00 & 1.53 & 6.11 & 6.17 & 0.146 \\
\hline Amble & 0.69 & 0.00 & 0.69 & 6.04 & 19.55 & 0.008 \\
\hline Seahouses & 0.90 & 0.00 & 0.90 & 1.80 & 0.70 & 1.000 \\
\hline Holy Island & 0.83 & 1.25 & 0.83 & 1.25 & 0.17 & 1.000 \\
\hline
\end{tabular}

The number of reciprocal information-sharing ties between successful fishers was greater than the number expected in all ports, with statistically significant differences in the distribution of ties in Amble and Blyth (Table 3). The most apparent exceptions were the two most successful fishers in Blyth (Fig. 2a) and Amble (Fig. 2b), who were frequently perceived as successful but did not engage in any reciprocal information-sharing relationships.

\section{Network position and fishing success}

Multiple regression showed a significant relationship between perceived fishing success and centrality measures $(F=17.954, p$ $<0.001$ ), although the fit explained a relatively small proportion of the variation $\left(R_{a d j}^{2}=0.446\right)$. Fishers with more incoming information-sharing ties were likely to be more successful $(\beta=$ $0.697, p<0.001$ ). Controlling for in-degree centrality, fishers with more outgoing ties were likely to be less successful, though this was not statistically significant at $\alpha=0.05(\beta=-0.297, p=0.063)$.

\section{DISCUSSION}

\section{Network structure}

We found evidence of a high proportion of fishers engaging in information-sharing networks at each port, suggesting that sharing is perceived to be a useful strategy. These results are consistent with a number of other studies that highlight the value of social relationships for sharing information on fishing catch and location (e.g., Palmer 1991, Gatewood 1984, Gezelius 2007, Mueller et al. 2008). Three reasons may explain the lack of information sharing among a minority of fishers (Gatewood 1984). First, fishers may lack the trust needed to establish information-sharing relationships, particularly if they are new to the fishery. Second, fishers may have alternative information sources; for example, in Northumberland former trawl fishers maintain ties with other trawling vessels, and fishers mentioned obtaining information from shellfish merchants. Third, fishing success is associated with pride and prestige in the lobster fishery, and some skippers may be unwilling to engage in informationsharing relationships as they perceive it would indicate weakness; one fisher stated, "If you were a serious fisherman you wouldn't want to ask." Pride and reputation may also have influenced some fishers' responses to interview questions, leading to an underestimation of information-sharing relationships and reciprocity. Although previous studies have identified a strong norm of reciprocity in fishers' information sharing (Gezelius 2007), a high proportion of relationships reported in Northumberland were not reciprocated. This may reflect unwillingness among some fishers to engage in, or admit to, sharing information.

We described four different network structures, reflecting the diversity of fishing ports within the NIFCA district. The mean number of ties, and mean number of reciprocal ties, held by each fisher was highest in the smallest network, Holy Island, where network density was highest. The fishing community in Holy Island comprises fishers who are on average older and more experienced, do not use any other fishing gear types aside from pots, and have a family history of fishing (Table 1). These factors may contribute to a long-standing network in which established trust allows greater information sharing and reciprocity. In small groups where trust is engendered by frequency of interaction (Ostrom et al. 1999, Dietz et al. 2003), the transaction costs of engaging in relationships may be lower, resulting in greater interaction among individuals (Rudd 2000, 2003, Grafton 2005, Sligo and Massey 2007). Greater numbers of ties in a network, and higher overall cohesion demonstrated by high density and low centralization, may influence information flow, indicating potential for greater exposure to new information that can contribute to knowledge (Bodin and Crona 2009). However, where fishers are very highly connected there may also be greater homogeneity of information received, and increasingly similar knowledge of fishing grounds among fishers (Bodin and Crona 2009). Such homogeneity has the potential to reduce the efficiency of resource use (Little and McDonald 2007) and reduce capacity to adapt to change (Bodin and Norberg 2005).

Subgroups can mitigate the potential negative effects of high network connectivity by enabling the development of specialized knowledge relating to fishing opportunities, thus a balance between high connectivity and subgroups is considered beneficial 
(Bodin and Crona 2009). In all networks except Amble, information-sharing networks formed a single weak component, indicating that information flowed directly or indirectly among all fishers. However, the number of strong components and isolates increased with network size. In the ports of Amble and Blyth, greater fragmentation and lower cohesion may be explained by greater diversity among fishers, with more fishers using multiple gear types and greater numbers of new entrants without a family history of fishing (Table 1). In contrast, fishers in Holy Island formed one strong component with no isolates, consistent with high levels of trust and reciprocity in small communities. The presence of strong components may also reflect the nature of fishing opportunities. A study of Alaskan salmon fishers speculated that size of information-sharing groups could reflect the optimum number of vessels per fishing spot (Gatewood 1984). Because information sharing is assumed to result in common knowledge regarding the location of target species and other vessels, larger groups may lead to overcrowding as a result of similar decision making, and may be detrimental to fishing success (Gatewood 1984). Overcrowding is considered a problem in Northumberland, particularly during peak season, when gear entanglement and conflict over space can lead to negative impacts on fishing efficiency. The presence of subgroups facilitating information sharing among small groups may help mitigate these problems.

Of the four ports, centralization was highest in Blyth and Seahouses, indicating that fishers had more similar ideas about people they wished to share information with there. Fishers in these ports were on average younger and less experienced (Table 1 ), and may have shared similar role models in the fishery. However, the highest centralization score was 0.52 (Table 2), indicating variation among fishers in who they decided to share information with in all ports. This may reflect differing ideas about which fishers were successful, or may reflect that tie formation may also be affected by other factors, such as kinship (for example, $40 \%$ to $63 \%$ of fishers in each port had family members engaged in the fishery, Table 1); age; spatial proximity; or similarity in fishing patterns (Henrich and Broesch 2011). Nevertheless, ties were not evenly distributed, indicating that receipt of information differed among individuals in the network, and positional advantages were therefore unequally distributed. Modeling work has shown that differences in network structure may have implications for resource exploitation patterns and efficiency; for example, those with closer links to skilled individuals may achieve greater success as a result of information flow (Little and McDonald 2007). Empirical research into these issues would need to distinguish such social effects from correlated effects; for example, differences among networks may result from differences in ecological variables or fishing practices (Conley and Udry 2010).

\section{Patterns of information-sharing relationships}

Our results support the hypothesis that fishers share information with those perceived to be successful, supporting the contention there are often leaders and followers in fishing communities (van Ginkel 2001). The results suggest that links may be formed in anticipation of receiving information from others (Conley and Udry 2010). These results are consistent with previous studies that found relationships between catch success and directionality of information exchange; a study of Mexican fishers suggested that less experienced fishers sought advice from those who were more experienced (Ramirez-Sanchez 2011), and in the Lake Michigan salmon fishery, fishers with below-average catch were observed sharing information with more successful captains (Mueller et al. 2008).

Modeling work suggests that some fishers ("cartesians," riskavoiders who stick to fishing grounds with the best known return) try to obtain information, but others ("stochasts," risk-takers who search for new productive grounds) try to avoid disclosing it (Allen and McGlade 1986). Our findings support this argument, because successful fishers were less likely to share information with unsuccessful fishers. Reciprocal relationships were also more common among successful fishers, supporting the contention that fishers tend to share information with others of similar skill levels (Acheson 1988). Similar findings have been identified in networks among farmers, where "veteran farmers" were found to share information more commonly than expected by chance (Conley and Udry 2010). The differing distribution of ties by success level was only statistically significant in Amble and Blyth, perhaps because of the smaller size of networks in Seahouses and Holy Island.

Future research could explore the benefits that less successful fishers perceive to gain from unreciprocated relationships with successful fishers, and also could investigate how fishers respond to any information they receive. For example, novice pineapple farmers in Ghana were found to respond to information about the outcome of using different fertilizer, particularly from more experienced farmers (Conley and Udry 2010). Similar research in a fisheries context would be useful to inform how social interactions have implications for fishing behavior and exploitation patterns, i.e., how fishers use the information they receive to make decisions about where and when to fish. Although this was not explored here, qualitative data indicated norms associated with sharing information; information was shared only with those trusted to use it considerately. One fisher stated: "Some people I wouldn't tell a thing to because they'd commandeer the place and take it off you." Such norms attached to information sharing are also found among farmers (Sligo and Massey 2007), and support the view that shared information may be important in long-term knowledge development. This is consistent with studies suggesting that individuals use information accumulated over long periods when deciding where and when to fish (Mikkonen et al. 2008).

\section{Network position and fishing success}

Only a relatively small proportion of the variance in fishing success was explained using centrality metrics. This is unsurprising, because there are many other variables associated with fisher characteristics and behavior that are likely to influence success, e.g., target species composition, number of pots, vessel size and engine power, and time spent fishing. However the results indicate that fishers' position in their information-sharing network was related to their success. Fishing success was positively related to in-centrality. Fishers with high numbers of incoming ties may have greater access to information that can inform their fishing decisions, contributing to improved knowledge of resource distribution and increased fishing success. Similarly, successful fishers in the Lake Michigan salmon fishery also had more ties and more reciprocated ties than less successful fishers 
(Mueller et al. 2008). Fishers with fewer incoming ties may receive less incoming information, potentially resulting in greater uncertainty in their decision making, contributing to lower success. Perceived success was negatively related to out-centrality (information shared with others), indicating that unsuccessful fishers shared information with more of their peers than successful fishers did. This is consistent with information-sharing patterns identified, which suggest that unsuccessful fishers form ties in anticipation of receiving information, but successful fishers may benefit more from reciprocal ties with experienced individuals. Although unsuccessful fishers may share with many individuals, successful fishers may have greater incentives to be secretive about good fishing grounds, allowing them to repeatedly return without further competition (Acheson 1981).

Although it is unclear whether fishers are successful because of their centrality in networks, or whether success contributes to their network position, there are likely to be iterative processes in which networks are both explanatory and outcome variables (Bodin and Crona 2011). Even though this study was not designed to test this, we suggest that successful fishers are likely to benefit from their position in the network. Whether or not successful fishers benefit from information shared by unsuccessful fishers depends on the quality of ties, including the salience and credibility of information shared (Hartley 2010). Although unsuccessful fishers may possess limited knowledge, they have an incentive to share reliable information with those with whom they seek to establish relationships. Recipients of information can assess its quality both immediately and over time, and sharing poor-quality information is likely to jeopardize chances of establishing reciprocal relationships with successful fishers (Mueller et al. 2008). Consequently, information received from less-successful fishers may contribute to the knowledge base of successful fishers.

\section{CONCLUSION}

Fisheries worldwide are facing challenges of overexploitation, creating demand for an improved understanding of social processes that influence fisheries dynamics (Crona and Hubacek 2010, van Putten et al. 2012). The UK shellfisheries sector has been overlooked in terms of its management needs, thus the results herein contribute to an improved understanding of fishers' behavior in Northumberland. Results highlight the tangible value social networks can play in supporting fishers' livelihoods. Information acquired can contribute to fishers' accumulated knowledge of the marine environment, aiding evaluation of decisions about fishing behavior and potentially conferring a comparative advantage (Holland and Sutinen 1999). However, the varying centrality of individuals in the networks shows that positional advantages gained through information sharing may not be equally distributed.

From a management perspective, the outcomes of informationsharing networks may not be compatible with fisheries management objectives. Although fishers equate high volumes of lobster landings with success, fisheries management must take a broader view that seeks to ensure long-term sustainability of resource exploitation. Research on lobster fisheries throughout the world illustrates how social adaptation and resilience may translate into short-term success for fishers, but can mask ecological feedbacks and potentially lead to increasing vulnerability to change in social-ecological systems (Huitric 2005, Steneck et al. 2011).
Nevertheless, understanding the dynamics of informationsharing networks can positively inform fisheries management, for example by helping managers pinpoint individuals who could help bridge information flows between fishers and managers. Fishers who are central in information-sharing networks are characterized by higher levels of fishing success and have access to a wide range of information from their peers. Identifying these fishers may be useful for managers seeking to collect information about the spatial and temporal distribution of target species and productive fishing grounds, the state of the fishery, and the ways in which fishers use their experience and accumulated knowledge to adapt to changes in the resource and the environment. Given their access to a range of information on others' fishing behavior, central fishers may be able to assist managers in anticipating the responses of the fishing community to change, and may help managers design management interventions that are appropriate to the social context.

The network structures examined here related explicitly to information sharing, but trust and social capital generated in such networks may also encourage the flow of other information or the development of norms and values (Bodin and Crona 2009, Ramirez-Sanchez 2011). Further research could examine how the structure and function of information-sharing networks may facilitate the development of shared norms and may enhance propensity for collective action (Rudd 2000, Pretty 2003, Ostrom 2009, Gutiérrez et al. 2011).

Responses to this article can be read online at: http://www.ecologyandsociety.org/issues/responses. $\mathrm{php} / 6456$

\section{Acknowledgments:}

This material is based on work supported by a NERCIESRC studentship. We thank the Northumberland fishers for their support and participation in the research, thank Fishery Officers at NIFCA for their assistance, and thank Clare Fitzsimmons for helpful discussions and comments on an earlier version of this manuscript. We are grateful to three anonymous reviewers, whose comments greatly improved the paper.

\section{LITERATURE CITED}

Acheson, J. M. 1981. Anthropology of fishing. Annual Review of Anthropology 10:275-316.

Acheson, J. M. 1988. The lobster gangs of Maine. University Press of New England, Hanover, New Hampshire, USA.

Allen, P. M., and J. M. McGlade. 1986. Dynamics of discovery and exploitation: the case of the Scotian shelf groundfish fisheries. Canadian Journal of Fisheries and Aquatic Science 43:1187-1200. http://dx.doi.org/10.1139/f86-148

Bodin, Ö., and B. I. Crona. 2008. Management of natural resources at the community level: exploring the role of social capital and leadership in a rural fishing community. World Development 36:2763-2779. http://dx.doi.org/10.1016/j. worlddev.2007.12.002 
Bodin, Ö., and B. I. Crona. 2009. The role of social networks in natural resource governance: what relational patterns make a difference? Global Environmental Change 19:366-374. http://dx. doi.org/10.1016/j.gloenvcha.2009.05.002

Bodin, Ö., and B. I. Crona. 2011. Barriers and opportunities in transforming to sustainable governance: the role of key individuals. Pages 75-94 in Ö. Bodin and C. Prell, editors. Social networks and natural resource management: uncovering the social fabric of environmental governance. Cambridge University Press, Cambridge, UK. http://dx.doi.org/10.1017/CBO9780511894985.005

Bodin, Ö., B. I. Crona, and H. Ernstson. 2006. Social networks in natural resource management: What is there to learn from a structural perspective? Ecology and Society 11(2): r2. [online] URL: http://www.ecologyandsociety.org/vol11/iss2/resp2/

Bodin, Ö., and J. Norberg. 2005. Information network topologies for enhanced local adaptive management. Environmental Management 35(2):175-193. http://dx.doi.org/10.1007/s00267-004-0036-7

Bodin, Ö., and C. Prell. 2011. Social networks and natural resource management: uncovering the social fabric of environmental governance. Cambridge University Press, Cambridge, UK. http:// dx.doi.org/10.1017/CBO9780511894985

Borgatti, S. P. 2002. NetDraw: graph visualization software. Analytic Technologies, Harvard, Massachusetts, USA.

Borgatti, S. P., M. G. Everett, and L. C. Freeman. 2002. Ucinet for Windows: software for social network analysis. Analytic Technologies, Harvard, Massachusetts, USA.

Borgatti, S. P., A. Mehra, D. J. Brass, and G. Labianca. 2009. Network analysis in the social sciences. Science 323:892-896. http://dx.doi.org/10.1126/science.1165821

Branch, T. A., R. Hilborn, A. C. Haynie, G. Fay, L. Flynn, J. Griffiths, K. N. Marshall, J. K. Randall, J. M. Scheuerell, E. J. Ward, and M. Young. 2006. Fleet dynamics and fishermen behavior: lessons for fisheries managers. Canadian Journal of Fisheries and Aquatic Sciences 63:1647-1668. http://dx.doi. org/10.1139/f06-072

Burt, R. S. 1983. Studying status/role-sets using mass surveys. Pages 100-118 in R. S. Burt and M. J. Minor, editors. Applied network analysis. Sage, London, UK.

Carlsson, L., and A. Sandström. 2008. Network governance of the commons. International Journal of the Commons 2:33-54.

Cashdan, E. 1983. Territoriality among human foragers: ecological models and an application to four bushman groups. Current Anthropology 24:47-66. http://dx.doi.org/10.1086/202934

Centre for Environment, Fisheries \& Aquaculture Science (CEFAS). 2011. Cefas stock status 2011: European lobster (Homarus gammarus) in Northumberland and Durham. CEFAS, Department for Environment, Food, and Rural Affairs, London, UK. [online] URL: http://www.cefas.defra.gov.uk/media/603083/ northumberland durham 2011.pdf

Conley, T. G., and C. R. Udry. 2010. Learning about a new technology: pineapple in Ghana. American Economic Review 100 (1):35-69. http://dx.doi.org/10.1257/aer.100.1.35
Crona, B. I., and Ö. Bodin. 2006. What you know is who you know? Communication patterns among resource users as a prerequisite for co-management. Ecology and Society 11(2): 7. [online] URL: http://www.ecologyandsociety.org/voll1/iss2/art7/

Crona, B., and K. Hubacek. 2010. The right connections: how do social networks lubricate the machinery of natural resource governance? Ecology and Society 15(4): 18. [online] URL: http:// www.ecologyandsociety.org/vol15/iss4/art18/

Department for Environment, Food, and Rural Affairs (Defra). 2010. Provision of sustainable access to inshore fisheries research gap analysis. Defra, London, UK. [online] URL: http://randd. defra.gov.uk/Document.aspx?Document=MF1209 9504 FRP.pdf

Department for Environment, Food, and Rural Affairs (Defra). 2011. Summary of responses to the consultation on domestic fisheries management reform in England. Defra, London, UK. [online] URL: https://www.gov.uk/government/uploads/system/ uploads/attachment data/file/120682/111108-fisheries-reform-summaryresponses.pdf

Dietz, T., E. Ostrom, and P. C. Stern. 2003. The struggle to govern the commons. Science 302:1907-1912. http://dx.doi.org/10.1126/ science. 1091015

Ernstson, H., S. Sörlin, and T. Elmqvist. 2008. Social movements and ecosystem services: the role of social network structure in protecting and managing urban green areas in Stockholm. Ecology and Society 13(2): 39. [online] URL: http://www. ecologyandsociety.org/vol13/iss2/art39/

Freeman, L. C. 1979. Centrality in social networks conceptual clarification. Social Networks 1:215-239. http://dx.doi. org/10.1016/0378-8733(78)90021-7

Freeman, L. C., A. K. Romney, and S. C. Freeman. 1987. Cognitive structure and informant accuracy. American Anthropologist 89:310-325. http://dx.doi.org/10.1525/ aa.1987.89.2.02a00020

Gatewood, J. B. 1984. Cooperation, competition, and synergy: information-sharing groups among Southeast Alaskan salmon seiners. American Ethnologist 11(2):350-370. http://dx.doi. org/10.1525/ae.1984.11.2.02a00080

Gezelius, S. 2007. Can norms account for strategic action? Information management in fishing as a game of legitimate strategy. Sociology 41:201-218. http://dx.doi.org/10.1177/00380$\underline{38507074797}$

Grafton, R. Q. 2005. Social capital and fisheries governance. Ocean \& Coastal Management 48:753-766. http://dx.doi. org/10.1016/j.ocecoaman.2005.08.003

Grant, S., and F. Berkes. 2007. Fisher knowledge as expert system: a case from the longline fishery of Grenada, the Eastern Caribbean. Fisheries Research 84:162-170. http://dx.doi. org/10.1016/j.fishres.2006.10.012

Gutiérrez, N. L., R. Hilborn, and O. Defeo. 2011. Leadership, social capital and incentives promote successful fisheries. Nature 470:386-389. http://dx.doi.org/10.1038/nature09689 
Hartley, T. W. 2010. Fishery management as a governance network: examples from the Gulf of Maine and the potential for communication network analysis research in fisheries. Marine Policy 34:1060-1067. http://dx.doi.org/10.1016/j.marpol.2010.03.005

Hartley, T. W., and C. Glass. 2010. Science-to-management pathways in US Atlantic herring management: using governance network structure and function to track information flow and potential influence. ICES Journal of Marine Science 67:1154-1163. http://dx.doi.org/10.1093/icesjms/fsq019

Henrich, J., and J. Broesch. 2011. On the nature of cultural transmission networks: evidence from Fijian villages for adaptive learning biases. Philosophical Transactions of the Royal Society 366(1567):1139-1148. http://dx.doi.org/10.1098/rstb.2010.0323

Hilborn, R. 1985. Fleet dynamics and individual variation: why some people catch more fish than others. Canadian Journal of Fisheries and Aquatic Science 42:2-13. http://dx.doi.org/10.1139/ f85-001

Hilborn, R. 2007. Managing fisheries is managing people: what has been learned? Fish and Fisheries 8:285-296. http://dx.doi. org/10.1111/1467-2979.2007.00263-2.x

Holland, D. S., and J. G. Sutinen. 1999. An empirical model of fleet dynamics in New England trawl fisheries. Canadian Journal of Fisheries and Aquatic Sciences 56:253-264. http://dx.doi. org/10.1139/f98-169

Huitric, M. 2005. Lobster and conch fisheries of Belize: a history of sequential exploitation. Ecology and Society 10(1): 21. [online] URL: http://www.ecologyandsociety.org/vol10/iss1/art21/

International Council for the Exploration of the Sea (ICES). 2012. Report of the working group on the biology and life history of crabs (WGCRAB), 14-18 May 2012. ICES CM 2012/ SSGEF:08. ICES, Copenhagen, Denmark. [online] URL: http:// www.ices.dk/sites/pub/Publication $\% 20$ Reports/Expert $\% 20$ Group $\%$ 20Report/SSGEF/2012/WGCRAB12.pdf

Johannes, R. E., M. M. R. Freeman, and R. J. Hamilton. 2000. Ignore fishers' knowledge and miss the boat. Fish and Fisheries 1:257-271. http://dx.doi.org/10.1046/j.1467-2979.2000.00019.x

Johnson, J. C., and M. K. Orbach. 1990. Migratory fishermen: a case study in interjurisdictional natural resource management. Ocean and Shoreline Management 13:231-252. http://dx.doi. org/10.1016/0951-8312(90)90004-2

Krackhardt, D. 1987. Cognitive social structures. Social Networks 9:109-134. http://dx.doi.org/10.1016/0378-8733(87)90009-8

Little, L. R., S. Kuikka, A. E. Punt, F. Pantus, C. Davies, and B. Mapstone. 2004. Information flow among fishing vessels modelled using a Bayesian network. Environmental Modelling \& Software 19:27-34. http://dx.doi.org/10.1016/S1364-8152(03) $\underline{00100-2}$

Little, L. R., and A. D. McDonald. 2007. Simulations of agents in social networks harvesting a resource. Ecological Modelling 204:379-386. http://dx.doi.org/10.1016/j.ecolmodel.2007.01.013

Maiolo, J. R., and J. Johnson. 1989. Discovering communication networks in marine fisheries: implications for management. Pages 69-80 in J. S. Thomas, L. Maril, and E. P. Durrenberger, editors.
Marine resource utilization: a conference on social science issues. University of South Alabama Publication Services, Mobile, Alabama, USA.

Mangel, M., and C. W. Clark. 1983. Uncertainty, search, and information in fisheries. Journal of the International Council for the Exploration of the Sea 41:93-103.

Marchal, P., B. Andersen, D. Bromley, A. Iriondo, S. Mahévas, F. Quirijns, B. Rackham, M. Santurtún, N. Tien, and C. Ulrich. 2006. Improving the definition of fishing effort for important European fleets by accounting for the skipper effect. Canadian Journal of Fisheries and Aquatic Sciences 63:510-533. http://dx. doi.org/10.1139/f05-238

Marín, A., and F. Berkes. 2010. Network approach for understanding small-scale fisheries governance: the case of the Chilean coastal co-management system. Marine Policy 34:851-858. http://dx.doi.org/10.1016/j.marpol.2010.01.007

Mikkonen, S., M. Rahikainen, J. Virtanen, R. Lehtonen, S. Kuikka, and A. Ahvonen. 2008. A linear mixed model with temporal covariance structures in modelling catch per unit effort of Baltic herring. ICES Journal of Marine Science 65 (9):1645-1654. http://dx.doi.org/10.1093/icesjms/fsn135

Mueller, K. B., W. W. Taylor, K. A. Frank, J. M. Robertson, and D. L. Grinold. 2008. Social networks and fisheries: the relationship between a charter fishing network, social capital, and catch dynamics. North American Journal of Fisheries Management 28(2):447-462. http://dx.doi.org/10.1577/M07-016.1

Northumberland Inshore Fisheries and Conservation Authority (NIFCA). 2013. Northumberland IFCA strategic environmental assessment scoping report. Mott MacDonald, Altrincham, UK. [online] URL: http://www.nifca.gov.uk/wp-content/uploads/2013/04/3035NIFCA-SEA-Scoping-Report1.pdf

Ostrom, E. 2009. A general framework for analyzing sustainability of social-ecological systems. Science 325:419-422. http://dx.doi.org/10.1126/science. 1172133

Ostrom, E., J. Burger, C. B. Field, R. B. Norgaard, and D. Policansky. 1999. Revisiting the commons: local lessons, global challenges. Science 284:278-282. http://dx.doi.org/10.1126/ science. 284.5412 .278

Palmer, C. T. 1991. Kin-selection, reciprocal altruism, and information sharing among Maine lobstermen. Ethology and Sociobiology 12:221-235. http://dx.doi.org/10.1016/0162-3095 (91)90005-B

Palsson, G. 1982. Territoriality among Icelandic fishermen. Acta Sociologica 25:5-13.

Phillipson, J., and D. Symes. 2001. Great Britain. Pages 97-980 in D. Symes and J. Phillipson, editors. Inshore fisheries management. Kluwer Academic, Dordrecht, The Netherlands. http://dx.doi. org/10.1007/978-94-017-1892-9 6

Prell, C. 2011. Some basic structural characteristics of networks. Pages 29-43 in Ö. Bodin and C. Prell, editors. Social networks and natural resource management: uncovering the social fabric of environmental governance. Cambridge University Press, Cambridge, UK. http://dx.doi.org/10.1017/CBO9780511894985.003 
Pretty, J. 2003. Social capital and the collective management of resources. Science 302:1912-1914. http://dx.doi.org/10.1126/ science. 1090847

Ramirez-Sanchez, S. 2011. The role of individual attributes in the practice of information sharing among fishers from Loreto, BCS, Mexico. Pages 234-254 in Ö. Bodin and C. Prell, editors. Social networks and natural resource management: uncovering the social fabric of environmental governance. Cambridge University Press, Cambridge, UK. http://dx.doi.org/10.1017/CBO9780511894985.011

Ramirez-Sanchez, S., and E. Pinkerton. 2009. The impact of resource scarcity on bonding and bridging social capital: the case of fishers' information-sharing networks in Loreto, BCS, Mexico. Ecology and Society 14(1): 22. [online] URL: http://www. ecologyandsociety.org/vol14/iss1/art22/

Rudd, M. A. 2000. Live long and prosper: collective action, social capital and social vision. Ecological Economics 34:131-144. http:// dx.doi.org/10.1016/S0921-8009(00)00152-X

Rudd, M. A. 2003. Accounting for the impacts of fishers' knowledge and norms on economic efficiency. Pages 138-147 in N. Haggan, C. Brignal, and L. Wood, editors. Putting fishers' knowledge to work. Fisheries Centre Research Report 11(1). UBC Fisheries Centre, Vancouver, British Columbia, Canada.

Salas, S., and D. Gaertner. 2004. The behavioural dynamics of fishers: management implications. Fish and Fisheries 5:153-167. http://dx.doi.org/10.1111/j.1467-2979.2004.00146.x

Scott, J. 2000. Socialnetwork analysis: a handbook. Sage, London, UK.

Sligo, F. X., and C. Massey. 2007. Risk, trust and knowledge networks in farmers' learning. Journal of Rural Studies 23:170-182. http://dx.doi.org/10.1016/j.jrurstud.2006.06.001

Smith, I. P., A. C. Jensen, K. J. Collins, and E. L. Mattey. 2001. Movement of wild European lobsters Homarus gammarus in natural habitat. Marine Ecology Progress Series 222:177-186. http://dx.doi.org/10.3354/meps222177

Steneck, R. S., T. P. Hughes, J. E. Cinner, W. N. Adger, S. N. Arnold, F. Berkes, S. A. Boudreau, K. Brown, C. Folke, L. Gunderson, P. Olsson, M. Scheffer, E. Stephenson, B. Walker, J. Wilson, and B. Worm. 2011. Creation of a gilded trap by the high economic value of the Maine lobster fishery. Conservation Biology 25:904-912. http://dx.doi.org/10.1111/j.1523-1739.2011.01717.x

St. Martin, K., and M. Hall-Arber. 2008. The missing layer: geotechnologies, communities, and implications for marine spatial planning. Marine Policy 32:779-786. http://dx.doi.org/10.1016/j. marpol.2008.03.015

Turner, R. A., T. Gray, N. V. C. Polunin, and S. M. Stead. 2013. Territoriality as a driver of fishers' spatial behavior in the Northumberland lobster fishery. Society \& Natural Resources 26 (5):491-505. http://dx.doi.org/10.1080/08941920.2012.709313

Van den Broeck, K., and S. Dercon. 2011. Information flows and social externalities in a Tanzanian banana growing village. Journal of Development Studies 47(2):231-252. http://dx.doi.

org/10.1080/00220381003599360 van Duijn, M. A., and J. E. K. Vermunt. 2006. What is special about social network analysis? Methodology: European Journal of Research Methods for the Behavioral and Social Sciences 2:2-6. http://dx.doi.org/10.1027/1614-2241.2.1.2

van Ginkel, R. 2001. Inshore fishermen: cultural dimensions of a maritime occupation. Pages 177-193 in D. Symes and J. Phillipson, editors. Inshore fisheries management. Kluwer Academic, London, UK. http://dx.doi.org/10.1007/978-94-017-1892-9 10

van Putten, I. E., S. Kulmala, O. Thébaud, N. Dowling, K. G. Hamon, T. Hutton, and S. Pascoe. 2012. Theories and behavioural drivers underlying fleet dynamics models. Fish and Fisheries 13:216-235. http://dx.doi.org/10.1111/j.1467-2979.2011.00430.x

Wasserman, S., and K. Faust. 1994. Social network analysis: methods and applications. Cambridge University Press, New York City, New York, USA. http://dx.doi.org/10.1017/CBO9780511815478

Wilson, J. A., and L. Yan. 2009. Self-organizing economic activity with costly information. Pages 2567-2574 in F. Rothlauf, editor. GECCO-09: Proceedings of the 11 th annual conference companion on genetic and evolutionary computation conference. New York, 2009. ACM Press, New York, USA. http://dx.doi. org/10.1145/1570256.1570363

Wilson, J. A., L. Yan, and C. J. Wilson. 2007. The precursors of governance in the Maine lobster fishery. Proceedings of the National Academy of Sciences 104:15212-15217. http://dx.doi. org/10.1073/pnas.0702241104 